\title{
A SNAPSHOT OF HAPPINESS: PHOTO ALBUMS, RESPECTABILITY, AND ECONOMIC UNCERTAINTY IN DAKAR
}

\author{
Beth Buggenhagen
}

\section{INTRODUCTION}

‘Adji Betty c Fanta. Je deux fille moi. Tu es au courant.' [Adji Betty, it is Fanta. I have two daughters. You are up to date now], wrote the daughter of a family that I had lived with during my fieldwork research trips to Dakar.

Our Facebook conversation in broken French continued as I replied, "What? You have two daughters now?"

And in Wolof Fanta replied, 'Bb nungi fii amna trois mois. Envoi des habits pr bb. Habit pr bb ke tu mave donne dafa bakh. Sama dome mougui sol yereyi ba legui.' [My baby is three months old. Send me some clothes for my baby. The clothes that you gave me were good. My child is still wearing them.] She was referring to clothing that I had given to her first child born two years earlier.

Through these brief Facebook conversations I kept in touch with women that I had come to know through fieldwork in Dakar, Senegal since the early 1990s. Cheaper than the phone cards I once bought and the cost of using Skype internationally, Facebook allowed us to

Beth Buggenhagen is Associate Professor of Cultural Anthropology at Indiana University, Bloomington and a Faculty Curator at the Mathers Museum of World Cultures. Her research interests include circulation and value, diaspora and transnationalism, neoliberal global capital, gender and Islam. She is the author of Muslim Families in Global Senegal, Indiana University Press, 2012. In her current research project, 'Visualizing the Senegalese Postcolony: Practicing Photography in the Urban Economy', she focuses on the relationship between official and unofficial economies and material and visual culture. Email: 
exchange photographs of our families and to chat on line. It had become part of my daily routine, logging on to Facebook to post photographs of my two daughters and checking to see if anyone had posted any new pictures from family events, parties, or religious holidays. I also kept up with members of this family who had settled in Montreal, Hartford, CT, Brooklyn, and Houston and started their own families. This had become my daily habit and an everyday activity that many of my friends in Dakar, who had Internet access thanks to a migrant sibling, engaged in. Yet I sensed that I, and probably they too, often forgot that these daily postings were really snapshots of momentary highs and not representative of the strains of everyday life, or even the stress of getting that perfect shot to post on line or put in an album. However, I contend that this endless stream of photos disguises this unremarkable reality. Facebook is the perfect medium for women to accomplish this social work, for it transfers to a digital medium what women have been doing for a long time, and what is the subject of this paper, which is making and looking at each others photo albums.

In this paper, I discuss the predicament of two women in the same family, Fanta and her sister-in-law, Amina. I show how these young women extemporize their respectability in a time of fiscal uncertainty through personal photography. Albums can potentially reveal social networks: number and frequency of invitations, density of social network, intensity of circulation, and the budget to purchase clothing for and to pay for pictures documenting this social activity. Not only are albums expensive, but also so are the social events that are worthy of photographs. A photograph involves more than just sitting in front of the camera-it entails particular ways to move from place to place such as by taxi rather than public transport, making one's way through the city with a particular rhythm requiring particular kinds of shoes and stacking bracelets that make the right sound - and the meaning of every step has an economic 
dimension. Successful albums index social networks that are constituted in and through ritual moments such as marriages, childbirth, and religious festivals. As I demonstrate in this paper, the making and meaning of these images develops out of various influences including colonial postcards, urban imagery, and Muslim iconography and reveals the extent to which these photographic practices are from their very inception global and transnational. Yet, rather than archives of the past, these albums, when they are successful, create social futures.

As much as albums can show the social possibilities and moral qualities of their bearer, they can also express inequality within the family, the neighbourhood, and the global. How do women like Fanta and Amina deal with economic and social disparity as they see it within their families, the various communities to which they seek to belong, and globally? The neighbourhood of Khar Yalla, is an improvised, interconnected, and multilayered space settled by families removed from the city center during clean up campaigns from 1960-1970, by families escaping conflict in Casamance and Guinea Bissau, and by recent rural migrants. As much as Khar Yalla is an improvised neighbourhood, it is also a space of improvisation. When women pose for, display, and pass around portraits of themselves at key moments in their lifetime, whether in the medium of social networking sites or photo albums, they reveal as much as they conceal the elements of individual and social life.

When women perform for the camera they index their urban neighborhoods not as peripheral, but as central to the city at large and to the lives and imaginations of their family abroad. Urban spaces, and especially the quartier populaire of Khar Yalla, are talked about by men and women in Dakar as loud, unruly, and fraught spaces with vast inequalities and incommensurabilities. How do women in these neighbourhoods actively shape and construct contemporary urbanity in terms of "social infrastructure" (Simone 2001)? Personal photography 
points to a social infrastructure and use of new technologies that connect where material infrastructure is disconnecting.

I had last seen Fanta during a visit to Dakar in December 2011. Since I had missed the birth of her first daughter less than a month before and the baby naming celebration, or ngénte, held seven days after, Fanta retrieved the slim vinyl photo album for me. I opened the album expecting to see elaborate cutwork, multiple exposures, and artistic photomontages commonly produced by commercial photographers across West Africa and which I had seen in countless albums during previous periods of fieldwork. Instead, the album sleeves held single $4 \times 6$ inch photos of Fanta's marriage, which had taken place two years ago in 2009, and her recent baby naming celebration. As I looked through the album some of the other family members in the room became quiet, some looked away toward the television, and a few left.

The album contained mainly portraits of Fanta alone and with her sisters and nieces seated on a couch facing the camera. Several of the photographs had been printed on stock paper with a simple red rose at the edge or a scroll. There were a few other images including her mother shaving the infant's head for the naming ceremony, and a group shot of the men assembled. The style of the album conflicted with what I knew of Fanta, whom I had first met as a 'sob,' or active, five year old in the spring of 1992. In contrast to her current style, which was youthful, edgy, and sometimes a bit shameless, these photographs portrayed a woman who might very well go unnoticed at a social event. In all, the photo album was consistent with the developments in Fanta's life that I had already heard about from her siblings over the past couple of years: the baby was born while the husband chosen for her continued to work in Spain's shrinking construction industry. The newlywed period was turbulent; the ngénte had taken place only in the morning without the gathering of women in the afternoon to exchange gifts of cloth. 
Moreover, Fanta was never brought into her husband's compound, an essential stage in the marriage process. Rather, she was in limbo so her niece offered to share her bed with Rama and the infant. Rama's niece had been moved into Rama's parents house when Rama's oldest sister divorced and left for the United States almost ten years earlier.

I asked her if she put her album together herself, 'Déedéet.' [No], she replied, 'Photokat mo ko def.' [The photographer did it.] Then she added, 'Maay na ay photo bi après.' [I gave some photographs away after.] In fact, women often swap $4 \times 6$ portraits of themselves with their close friends by removing them from their album sleeves and replacing the empty spot with a friend's portrait. This is one of the ways in which women index social networks and make them visible to other audiences. Through these photo albums women look forward creating and expanding networks, rather than keeping family histories.

Fanta said that she wore the three different outfits for the album and only two of them the morning of the baby naming ceremony; these were dresses made from ten meters of locally dyed cloth known as a grand boubou. I told her that I thought the ensembles were 'Rafet na' [Beautiful]. In response, she then brought out another piece of her outfit that was not visible in the portraits, which were $3 / 4$ bust shots. She showed me a single piece of locally woven strip cloth called sër-u-rabbal, six bands of cotton cloth sewn together to form a wrapper. She explained that her mother's sister gave her the wrapper to commemorate the birth of this first child. It was deep aubergine cotton woven with silver Lurex thread. ${ }^{1}$ It was the first of many such wrappers that a woman aspires to accumulate and redistribute during her lifetime during baby naming ceremonies, weddings, and funerals.

I asked to interview Fanta's photographer. Fanta's niece and sister-in-law, Amina, who had remained in the room, replied in unison, 'Baay ko' [Leave it], to indicate that I should let the 
subject drop. This is a phrase I had heard many times spoken to myself and to others to pull back or to retreat from a line of argument. I chose not to inquire further understanding that the marriage process and the baby naming ceremony had been modest affairs given the fraught nature of Fanta's marriage. I surmised that the family was pointing me toward more successful unions and celebrations; events that brought them more joy and pride. I thought this because Fanta's niece and Amina then directed me to Amina's photographer's work, which they described in contrast to Fanta's photographer's work as 'Baax ne' [Good]. They explained that unlike many commercial photographers who rented their cameras from studios, Amina's photographer, Alpha, had acquired a studio space Khar Yalla. Though he took pictures in his studio against various backdrops featuring tropical themes and silk flowers and offered a panoply of props to his clients, these three women with social aspirations (Fanta, Amina, and Fanta's niece) said such practices were old fashioned, 'démodé' or 'xewwina,' and left the practice to older men and women and new migrants to the city. ${ }^{2}$

The young women said that they preferred to have their photographs taken against the backdrop of their own living room to show potential audiences their handsome things, 'Meubles yi, rideaux yi, lampe bi' [Like furniture, curtains, and lamps], said Fanta as she pointed around the room and explained that her brothers had purchased many of these items after going abroad. After all, many of the valued objects owned and displayed by women were the product of complex social networks and negotiations of buying, borrowing, and gifting. Thus a photograph could demonstrate a woman's social sense or skill in managing social relations and acquiring new things.

Amina then climbed the stairs to her room and brought down one of her albums as she explained to me that many women might have as many as three albums to hold photographs of 
their first child and that with subsequent children there might be less effort and expense. She handed me her album and I realized that its weight required both of my hands to receive it. She laughed and asked, 'Diis na?' [Heavy]? Amina had brought me her wedding album. The leather like bound album contained $8 \times 10 \mathrm{~s}, 5 \times 7 \mathrm{~s}$ and $4 \times 6 \mathrm{~s}$. Almost all of the images were taken at her in-laws' home where she now lived with her husband. There were three quarter bust portraits focused on her face and shoulders with lighting that illuminated her skin against the backdrop of heavy curtains, velvet upholstered couches, and silk flowers. As I thumbed through the double and multiple exposures of Amina, including one in which there were seven of the same portraits arranged in a montage, Fanta's niece said several times 'Waay yo, Amina, danga jekk' [Hey you, Amina, you are elegant]! There were similar poses with sisters and sisters-in- law appearing singly and then in multiples as though they were looking through a disco ball or a set of mirrors.

Sometime they appeared in symmetrical oppositions, and on other pages Amina was at the top of the hierarchy of repeating images. There were also portraits of Amina in various poses that I saw commonly among Dakar women. She posed in a squatting position with her chin on her hand or she lounged on a bed. There were also full-length portraits of her as though she were walking into the room offering a sense of movement to the static image. ${ }^{3}$

\section{PHOTO ALBUMS AND CREATING A SPACE OF RESPECTABILITY IN KHAR YALLA}

Over the decades that I have worked in Khar Yalla since the 1990s, Dakar has been a locus economic volatility wrought by structural adjustment plans, privatization schemes, and liberalization of the economy. And nowhere is that volatility keener than in Dakar's improvised settlements: Colobane, Grand Yoff, ${ }^{4}$ Pikine, and many others. The current administration of President Macky Sall continues to be plagued by political and economic problems: land grabs, 
building collapses, political mendacity, a swelling of ranks of unregulated peddlers and child talibe,${ }^{5}$ and a disproportionate share of wealth going to a few fortunate Senegalese. Young women, such as Fanta, seem most vulnerable to misfortune. Where many have fashioned their productivity and respectability through membership in the Murid Sufi congregation and their overseas trade circuits, not all young women have had the option to travel available to them. Though many sought to be married to these transnational traders, by the 2000s, such marriages had ceased to guarantee the evidence necessary to demonstrate middle class respectability that they once did. Many of these marriages were not to the prosperous traders who are frequent fliers and customers of shipping companies who move their goods, but to the young men who risked their lives on high seas in dangerous open wooden pirogues headed for Spain. So these young women sought other ways to achieve respectability.

A portrait, unlike a snapshot, is the way in which a subject presents herself to the world. The desire to present an image of respectability, as expressed through the concepts of am kersa [restraint], jekk [elegance], or rafetlu [beauty], is one of the reasons that women say that they make albums. Women strive to maintain social decorum and to be jekk despite the ups and downs of their personal finances and the turbulent times in which they try to stay afloat. As a project of fantasy, these albums are less about archiving the past than demonstrating potential. The success and failure of Amina and Fanta shows how women aspire to use photo albums to create a space of respectability for themselves in an urban milieu that offers many distractions for young women. A well-posed photograph held the power to persuade others of one's wellbeing and self-possession. Young women can turn to properly composed portraits to alleviate a family's anxiety that left unattended by husbands' abroad, or remaining unmarried past a respectable age, one might become sexually promiscuous. 
One can look at the circulation of portraits as a network, and an album is a particular kind of network. Where infrastructure may have broken down or be disorderly, or conventional forms of citizenship and belonging difficult to identify, these social networks provide a different view of urban life. Photography has come to reflect not only the changing fortunes of individuals and families, but transformations in urban landscape itself. These performances, and the networks they constitute, shape and are shaped by their subjects' relationship to the capital city. Khar Yalla's early residents were evicted from the city centre of Dakar between 1960 and 1970 as the city razed self built structures for middle class housing. Rather than being bound by the peripheral nature of their neighbourhood, Khar Yalla, women's performances are both motivated and constituted by links to middle class and expatriate neighbourhoods in other parts of the city to the rural capital of the Murid Sufi congregation Tuba, now Senegal's second largest city after Dakar, and to cities overseas in Europe and North America.

African urban spaces are often depicted as sites of atrophy and decay (Davis 2006, Watts 2005), yet they are vibrant centres of cultural production and places where residents ingeniously deal with economic uncertainty. People appreciate pictures of themselves looking good because everyone knows the hardships that they are all up against regardless of where they are on the economic ladder. In their visual practices and use of new technologies, such as digital photography, social networking sites, and cell phone cameras, these urban spaces are progressive sites of inspiration and invention (Mbembe 2004). That creativity may often be both inspired and tempered by hard times wrought by a long history of encompassing global volatility (see for example Makhulu et al. 2010). As many of these visual practices and the circulation of new technologies takes place outside of the official economy, the relationship between media and 
technology and the articulation of new spaces of operation beyond the official economy suggests yet another strategy for dealing with economic uncertainty (Larkin 2008, Simone 2006).

Photo albums make visible at home a vast circulation of wealth (or the image of wealth at least) produced by Murid overseas traders through unregulated economic networks. Many Murid women of diverse economic means seek to create their social and moral selves through photographs despite their daily sense of privation. Through photo albums women endeavour to create a space of respectability and reputability especially when the conventional means to do so are unobtainable. These photographs mediate, or create meaningful links, between their experience and the broader economic transformations into which they are thrust. Through such processes of mediation persons create and contest value and meaning (Brennan 2010, Hirschkind and Larkin 2008, Mazzarella 2004). By focusing on how women control the circulation of images to reveal and conceal the proceeds of migrant work we can understand how women create value over a transnational space in the context of the longer history of turbulence that characterizes West African economies (Appadurai 1986, Comaroff and Comaroff 2001, Foster 1993, 2006, Guyer 2004, Keane 2001, Mauss 1990 [1950], Munn 1992, Strathern 1988, Weiner 1992). Moreover, we can also understand the city as a complex, varied, and multi-layered space of different possibilities and impossibilities.

One of the layers of urbanity in Dakar is the influence of Islam. I focus on how Muslim women consider the efficacy and aesthetics of personal photography in relationship to Sufi concepts of luck (warsek), and religious grace (baraka). In so doing I build on the work of other scholars of Islam who have been concerned with how media practices in Muslim communities (Eickelman and Anderson 2003; Eisenlohr 2006; Hirschkind 2006; Larkin 2008; Meyer and Moors 2006; Schulz 2006) extends recent work on media ethnography (Ginsburg et al. 2002; 
Wilk and Askew 2002) by demonstrating local religious meanings of a universal technology. I also argue that rather than seeing photography as an instrument of colonization, we might consider how Muslim women in Dakar use photography to create a space of respectability.

Scholars of Senegal and the Gambia have focused on photography in the studio (Buckley 2000), in fashion (Mustafa 2002; Rabine 2010), in the political imagination (Bajorek 2010), and among Muslims (Roberts and Roberts 1998). Photographs are documentary, commemorative, a form of reportage, persuasive, and everlasting (Mustafa 2002: 172). They concretize vast social networks of circulation as well as themselves become objects that circulate. Muslim women's portraiture expresses the paradox of 'keeping-while-giving' (Weiner 1992); for the danger in making wealth visible, or allowing it to circulate, is that it can be lost. Other qualities can be lost as well such as a family's good repute.

\section{THE HISTORIES IN SENEGALESE PHOTOGRAPHS}

The $20^{\text {th }}$ century has seen two photographic revolutions that have led to the expansion of photography in Africa and elsewhere: the Kodak revolution at the beginning of the $20^{\text {th }}$ century and the digital revolution at the end of the 21 st century, both of which exacerbated the qualities of movability and reproducibility that Walter Benjamin (1978) used to differentiate photography from art. Focusing on these qualities lead us away from looking at African photography as art in the service of colonialism as much of the extant literature on photography in Africa does (Landau and Kaspin 2002), to see how the camera and photography have become at each turn a form of everyday material culture. Contemporary photographic practices have emerged out of a complex visual economy with multifaceted historical and spatial references, including colonial postcards, Islam, and studio portraiture, and transnational collaborations with links to very 
different spheres of value. As I will argue, the reproducibility of colonial postcards and religious images has contributed to their current circulation and their influence over contemporary images. My approach to visual economies in Muslim Senegal then breaks with the conventional distinction analysts make between photographer, subject, and viewer. This distinction has been important in terms of brining to light power relations between colonizer and colonized and the role of the visual in such regimes of power. If a portrait is a way in which the sitter presents herself to the world, its opposite is the colonial postcard in which the sitter is presented to the world as an object to be looked upon (Prochaska 1991: 46). As early as the 1840s French adventurers, missionaries, and ethnographers were 'instrumental in affirming visual codes and stereotypes through which the West interpreted Africa and its peoples' (Lamunière et al. 2001: 13). In West Africa, the French produced 8,740 postcards; of those 7,210 were produced from 1901-1918. There were 310 studies of women and girls in so called ethnic dress (Mustafa 2002: 175). Many images portrayed women as partially nude, reclining, or posing in similarly sexualized ways and were often accompanied by commentary that was at once romantic, racist, and sexist. One of the largest producers of postcards in Africa from 1899-1920 was FrançoisEdmond Fortier (Figure 1) Reproductions of these postcards still circulate globally, contemporary postcards for sale in Dakar still reference these images, and contemporary artists working in the medium of photography often play with and comment on these earlier influences on the trajectory of photography in the country.

Other images in contemporary circulation include those taken by French colonial officers to document the activities of Muslim shaykhs that were suspected of resistance. These images were appropriated and invested with new meanings by the disciples who used these images in their devotional practices. For example, the French only snapped one photograph of the founding 
figure of the Murid way, Amadou Bamba, and its singularity over time became the basis of its reproduction as a devotional image in wall murals, hanging photographs, and in necklaces (Buggenhagen 2010). These images 'get things done...they are endowed with baraka...Mouride visuality is above all directed toward practice' (Roberts et al. 2003: 76). For Murids, images of Bamba are talismanic. Bamba's imagery attracts grace and thus prosperity. These images draw on the tension between zahir, the visible, and batin, the invisible (Roberts et al. 2003: 95).

Where photography had been central to the civilizing mission of the French, in time photographs came to define the civilized classes in the four communes and especially in Dakar. Personal portraiture differs from its colonial predecessor in that it cannot be well understood in terms of the relationship between photographer, subject, and viewer, but rather in terms of the complex negotiations that take place between photographers and their clients (Bigham 1999). Moreover, unlike the generic nature of colonial postcard portraits which were often reprinted, African portrait photographers usually only produced a singular image to commemorate a particular event. Throughout the late $19^{\text {th }}$ and early $20^{\text {th }}$ century Senegalese metis known as signare were sitting in high backed Victorian chairs for portraits in their homes in St. Louis (Jones 2013: 93). As early as 1860s St. Louis, Senegal had the first daguerreotype studio (Chapuis 1999: 49). By 1912 personal photo albums had become popular for urban residents of St. Louis through the Senegalese photographer Meissa Gaye. In the 1940s Mama Casset opened his studio in the Medina neighbourhood of Dakar, African Photo. Casset learned photography from Oscar Lataque after joining the French air force where he took aerial photographs during the war. Unfortunately Casset's studio burned down and the only available photographs are from the negatives supplied by Madame Casset for a volume published by Editions revue noire. 
As West African photographers turned cameras on their own societies the novelist Aminata Sow Fall remarked,

The arrival of photography must have been seen as a gift from the gods, to conspire against the grotesque and often insulting caricatures produced by the colonists. We could finally all enjoy looking at ourselves in a snapshot of happiness; immortalized on a card... a photograph should only reflect the beautiful, admirable, dazzling side of our existence. That is why we were photographed for major ceremonies. (Fall 1999: 64)

Portraits worked their way into wedding exchanges through the practice of xoymet. When the bride entered her groom's home for the first time, she would encounter his room decorated with images of her borrowed from friends and family (Mustafa 2002: 176).

Senegalese photographers partly adhered to the standard conventions of studio portrait photography including 'compositional centrality, full-length figures shown frontally, shallow pictorial space and the incorporation of backdrops and accessories' (Lamunière et al. 2001: 14). However Senegalese portrait photographers also tended to focus on the upper body and the face, which was illuminated with the artificial lights of the studio. Women's hands were often posed to frame their faces, and to accentuate their eyes. Casset's portraits, like those of other photographers of the era, can be characterized by tight framing, structured composition, a preference for slants and diagonals, the skilful arrangement of cloth and clothing as well as attention to bodily expression (Figures 2 and 3). Mama Casset, like his contemporary the Malian photographer Seydou Keita, employed the angled bust portrait; 'in this pose the sitter's face was captured in a three-quarter view, with the body appearing to lean toward the edge of the picture 
frame' (Lamunière et al. 2001: 29) or to 'lean out of the frame' (Mercer qtd in Bell et al. 1996:30).

\section{PORTRAITURE, PERFORMANCE, AND URBAN SPACES}

Social discourse in Khar Yalla focuses on disconnections: electrical outages, water shut offs, lack of trash pick up, and paved sidewalks and streets, as failures of the state to recognize the neighbourhood in its entirety with its unofficial settlements. The rappers Xuman and Keyti joke on their weekly television show Journal Rappé about the electric utility SENELEC as COUPELEC from couper, or to cut in French, referring to frequent power outages in different city neighbourhoods. 'Investissez dans le sondeel.' [Invest in candles], they tell their audiences. Yet residents create other networks that overlay this decaying, dormant, or deficient infrastructure. African urban spaces are comprised of an assemblage of networks at once technological and cultural, the hard infrastructure that links up places across the globe and the social networks along which goods and ideas circulate (Larkin 2008: 6), or what I referred to in the introduction as the "social infrastructure" (Simone 2001).

Khar Yalla women have had to perform the work of creating social networks with ever more inventive ways of coming up with the means to appear glamorous, make social payments, and pull off family celebrations (Buggenhagen 2011). Through photography, women perform their connections to the multi-layered urban spaces of Dakar, which are both content for and the context of their images (for further discussion of the city and of photography see Magee 2007). Behind the multiple visual layers these images also reveal the overlapping of religious, economic, and social spheres that characterize urban life. Photographs, as performances of reputation and social station, suggest vitality in an urban setting that is often described as jaffe, or difficult, and that has come to be defined by its vast disparities in wealth and welfare. 
Performances, for the camera and for other women who view their albums, index the networks through which women construct their neighbourhood as part of the urban fabric of Dakar-a cosmopolitan capital city—rather than as peripheral to it.

The time that women spend with each other is often spent looking at photo albums and these albums are an especially important part of meeting new people. Thus the album and its viewing creates a spatio-temporal space. Viewing these pictures is pleasurable; often women recount the photograph of themselves taken at the family or religious event more often than their experience of the event itself such that the photograph is as an essential element of the self. There is a temporal dimension to these still images; the self women are most interested in is not who they were in the past; rather, their potential selves. As projects of potential social futures, portraits convey a notion of future time, of concern for reciprocity over time. Dakaroise are proficient at looking, sizing each other up, and speculating on the limits and possibilities of each other, whether in the market or at a family ceremony or religious festival. Through these performances, of looking and being looked at, of indexing this network culture through personal photographs, women anticipate a 'retomber,' or a payback. (see also Grabski 2011 for further discussion of the idea of Dakar as a network culture).

The process of viewing albums involves a narration by the subject herself to provide context for the event and the meaning of the image. Through this performance, women control how their images are viewed. Rather than detailing the event, such as 'and then I was married,' or 'just after I had the baby,' women make a visual argument for their social ascent. Moreover, albums juxtapose multiple images of a social actor, multiple portraits of the subject in various social contexts over time to make a visual argument about her social standing in society and her capacity for redistribution. For example, as I mentioned at the outset, as Fanta was showing me 
her album she described the outfits and their origin saying 'and this is the ensemble my aunt gave me,' and 'this is the ensemble my in-laws provided,' and then retrieving for me the items that were not visible in the picture such as the woven wrapper. Fanta had effectively laid out a narrative of relations of reciprocity for me as the viewer to place herself in her desired social context.

\section{Photographers, Studios, and Album Aesthetics}

For many young women, there is a near economic impossibility to produce an album and thus difficulty in performing respectability for oneself and one's family. Unmarried women rarely have albums, they usually have packets of photographs or individual portraits propped on their bureau or tucked in a mirror frame. Women buy these photographs from itinerant photographers who take their pictures at family celebrations and religious festivals. In contrast, a family may hire a photographer for an event that they are hosting and have an album made afterward. Most of the photography takes place in the social setting of the home with the exception of several portraits that may be taken at the beauty salon. Each occasion has a typical aesthetic tied to it, and those particular styles tend to influence other images. For example, women returning from the Hajj would have a portrait of themselves wearing all white with a large white scarf draped over their head and shoulders, and women who had yet to go on the Hajj would also drape a large white scarf over their head and shoulders for religious events. A woman headed out to a family celebration may also choose to wear all white, as it is associated with Muslim virtue. Such images may stand in where in image of oneself returning from the Hajj has yet to be obtained.

Digital cameras, first introduced in the 1990s, have expanded the unofficial economy of commercial photographers who are self taught as the technologies allows them to take many 
more images to get one good one. These photographers rarely own their own studios or equipment; they rent their cameras from studios often owned by East Asians who were in Dakar in the 1980s and 1990s. These enterprising photographers take to the street in search of an event worth photographing looking for tell-tale signs such as a large tent erected in front of a home, livestock tethered to a post, or the beat of sabar drums and a sound system broadcasting Muslim litanies.

The photographer can charge many ways. A single photograph in 2000 could cost 500 CFA francs. ${ }^{6}$ A photographer hired for an entire day for an event could charge at least 100,000 CFA. A photographer could also charge the client by the number of photographs; an album of 80 photographs could cost 70,000 CFA or one of 60 could cost 50,000 CFA (Fabienne Ngoone Diouf, personal communication, June 2013). Of course there are other costs to photography as well. The cost of the clothing could run $\$ 100$ US for first quality fabric hand dyed in Mali, or $\$ 100$ US for an outfit that has already been tailored and embroidered from an inferior dyed cloth, plus accessories, a trip to the salon, a gift for the event, and taxi fare as a woman cannot arrive in a car rapide or on foot.

As I mentioned, rather than viewing African photography in terms of photographer, subject, and viewer, personal photographs are the result of complex negotiations between clients and photographers. The ways in which photographers work with their clients, the ways people view and appreciate photographs, and the aesthetics of photographs has changed as economic prospects have fluctuated over the decades. In post-war Senegal and The Gambia photographers might have their own studios, own cameras, and even have some professional training. These photographers sought to capture their subject's jikko, or persona, through their skilful touch arranging the body in a pleasing way. 
Today, photographers avoid handling their subject's jikko, which they describe as too volatile or dangerous (Buckley 2000: 73). The skifful arrangement of the body has been replaced by the strategic positioning of props and backgrounds. In Khar Yalla, clients are more concerned with capturing the contexts in which the photograph is taken to instantiate their social position. As Fanta told me just after her marriage in 2009 'I would never have my picture taken in a photo studio. Everyone would know that backdrop was full of studio props. In my home, everyone knows that the items belong to me.' Although studio photography may not be thriving for urban women who seek to distinguish themselves as those who have ties to migrants abroad, rural migrants to Dakar continue to visit studios to have their portraits made. The professional photojournalist and artist Djibril Sy described the return of Serer migrants to their natal villages in this way, 'they line up their chariots (horse carts) and each head of the family has with him his photo album and they continue in this progression out of Dakar toward their rural residences.' (Djibril Sy, personal communication, 2011)

Young urban women also appreciate the surface appearance of the photograph such as the montage, rather than the photograph's capacity to convey their authentic selves or moral personhood, in short, their jikko. Thus, Senegalese personal photography, like elsewhere on the continent, tends to favour multiple exposures, cutwork, and photomontage (Behrend 2010; Buckley 2000). Photographers often reproduce many copies of the same image to collage together, manipulate the image through cutwork with a razor upon the surface of the print, or use digital manipulation to produce signage, repetition, and montage. For example, popular images include double or multiple exposures, a montage of twins or co-wives, a mother and her daughter, a child and their deceased parents, and religious figures. Photographers also make photo collages incorporating magazine clippings into the finished images. Wedding albums often 
feature images of the bride or of the bride and groom with romantic sayings and motifs such as hearts and flowers cut into the surface of the printed image with a razor blade. Double exposures are especially common among migrants. One young woman in her teens in Dakar had created a digital image of herself with her mother, who had been in the US for over ten years, sitting behind her shoulder and posted it on Facebook.

Because Senegal is 95\% Muslim, many of the images that appear in women's albums are of their presence at religious festivals. Commercial photography is highly influenced by dynamic Sufi visual practices emphasizing repetition and montage. These images play with Sufi ideas of the hidden (batin) and the seen (zahir); they reveal as much as they conceal the elements of individual and social life at different moments in time.

\section{Multiplying Surfaces}

A good photographer is as essential to a woman's social prominence as a good tailor and good hairdresser. Photographers, like griots, hold the power to make or break reputations and are paid for and sought out by powerful women. As much as photographers vary in their skill, so too do their clients vary in the their social proficiency. Amina's album, which contained multiple exposures, a dizzying array of cutwork and signage, and showed the skilful hand of a talented photographer, also displayed her own social aptitude. Amina married a son from a successful family who lived across the street before she was twenty years old and protected her propriety. Both families were invested in the success of the marriage. Her husband had built a private suite for her in his parent's home so that she had both her privacy and prestige, but also the support of the larger household in carrying out mundane tasks like cooking, housework, and childcare thus freeing her for social activities. Since her marriage, Amina had given birth to several children, 
two boys and a girl. Unlike many of his older brothers who had gone overseas, Amina's husband remained with her in Dakar managing his older brother's tile shop. Amina's album reflected the investments that others had made in her, the photographer who had standing in the community, her husband, and their two families.

In contrast, family members described Fanta's marriage as jaffe, or difficult because, "Adja? bare na dox. She got around." Some families will marry a girl swiftly if they become concerned about her protecting her modesty. Fanta was somewhat of a disquette, a young woman who delighted in fashion, music, and parties. The families had hastily arranged her marriage to a distant relative on her mothers' side of the family (which is not the preferential marriage for Wolof which would be father's brothers son), a Murid man working in Barcelona's construction industry but then he suffered financially from the global downturn that bankrupted Spain. The austereness of Fanta's album reflected our conversations about the shaky nature of her marriage, which she had tried to exit several times in the three years since it had been tied at the mosque. In fact, during my visit in December 2009 they had separated because he was often not able to reach her on the cell phone that he bought her and became suspicious. He soon ceased financial support and eventually they stopped speaking. Fatou had first privately shown me the album in 2009, because her family had concluded that her husband would divorce her.

In Amina's album one can see a performance of the self and an explicit attempt to 'come out better,' which was the result of a productive collaboration between Amina and her photographer Alpha. In relation to Stephen Sprague's (1978) work on Yoruba images, Christopher Pinney remarks upon subjects 'concern with the surface of the image and its production after its photographic moment is manifest' (2003b: 218) and how in Indian photography subjects seek to 'come out better.' Thus rather than seeing Fanta and Amina's photo 
albums as 'a window on reality,' I would argue that their personal portraits are 'a surface, a ground, on which presences that look out toward the viewer can be built' (Pinney 2003b: 219). Thus one cannot easily separate the subject of the photograph from the viewer as the former is actively trying to influence the latter through her performance and later narration of what is to be seen. Many of the images in Fanta and Amina's albums, indeed in many of the albums I have viewed over the decades, have a quintessential shallow picture space common among African photographers that brings attention to the substance, or what emerges after the moment that photograph is taken (Oguibe qtd in Bell et al. 1996: 246). Thus viewers often comment on 'the mysteries of exterior appearance' (Wendl 1999: 154 qtd in Buckley 2000: 71), and photographers seek to produce 'multiplying surfaces' (Buckley 2000: 83).

Alpha has successfully managed to 'multiply surfaces' and to produce multiple views, and thus meanings, by cutting the portraits of Amina into montages. His work was in the style of many of the portrait artists of religious leaders in Senegal. A common photograph that Murid disciples use as a talisman can be bought in the market. It is a collage that depicts all of the Murid shaykhs, from the founding figure of Amadou Bamba who died in 1927 to the present. ${ }^{7}$ (Figure 4) The montage of Murid shaykhs creates a spatio-temporal domain in which disciples and guides can dwell simultaneously in and out of time. Similarly, when disciples have images of themselves with religious figures in the mix a visual relationship is created between the two subjects. Such proximity to the divine then lends itself to the receipt of baraka.

The meaning of these images is not fixed; images gather new meanings as they circulate in new contexts and are viewed by different audiences. Yet, every time Amina brought out her album to show to a visitor to her home, she augmented her reputation of not only being recipient of wealth, but also being in a position to distribute it on future occasions. As a memento, or 
future reminder, then, she might offer to give her viewer one of her photographs. The multiple images of herself were the product and the potential for her abundance. This relationship between 'discursive formations and image worlds' (Freedberg 1989: 35 qtd in Roberts et al. 2003: 22) is ever shifting allowing for what Pinney (2003a: 6) calls the 'transformational potentialities' and 'volatility' of photographic practices.

\section{Just Posing?}

The silence surrounding Fanta's album on the two occasions that I viewed it in 2009 and 2011 was telling. In our conversations, Fanta seemed to be struggling with the idea of marriage as the only path to social respectability. Rather than expressing her concern to come out better in her portraits, the album expressed her family's efforts to repair the rupture caused by a marriage gone awry by producing a photo album that showed a linear progression from marriage to motherhood. Men often provide financial support for women's social endeavours because they are concerned about family reputation, which is primarily in women's hands in their absence.

In their portraiture, women perform sañse, or dressing up (Heath 1992: 23). Through portraiture, women convey an image of themselves as smartly dressed and favoured by their husbands, who may already have other wives, or whom the idea of other wives remains a potential. (Figure 5) Thus they position themselves with the potential to bestow that wealth on others. Beauty and generosity are a sign of inner grace, or baraka.

In fact, personal portraits from religious rites surrounding weddings, baby naming ceremonies, holidays, and festivals that make up women's albums have many influences including that of Islam. The practice of photography and the meanings attached reflects the shift from Murid engagement in a rural sphere of agricultural production to the urban sphere of 
exchange through transnational networks. Murid women's portraits are influenced by Sufi thought and practice including the possibility of a 'retomber,' or a payback, from a successful performance of respectability; these images, like photographs used as religious talismans, hold the potential to be generative of something else. Photographs, like many aspects of Sufi life, are thought to 'possess a secret side', or batin, 'the insightfulness of not seeing, then, is often believing' (Roberts and Roberts 2000: 47). It is this relationship between 'display and secrecy [that is] essential to Mouride visuality' (ibid: 80 ). The relationship between visibility and invisibility, the known and the unknown, can be understood by looking at the shift from capturing one's jikko, or inner essence, to one's surface in which one hopes to 'come out better'.

Portraiture has as much to do with love and beauty, as neglect, despair, and the attempt to conceal inequality (see for example Poole 1997) and I started this paper with Fanta's album to convey this point. The flip side of sanse, or dressing well, is pukaare, or posing, which reveals too much. Many Senegalese women cannot sustain their reputations, except in their photographic representations. Women accused of pukaare often obtain money from outside lovers or rack up insurmountable debts with usurious vendors. For this reason discretion, or sutra, is central to concealing debt and making visible wealth, honour, and restraint. Thus the portraits convey their inner secrets, their batin, or the unseen workings of the divine, and their indiscretions, or their proclivity for debt.

Rather than focusing on these portraits as a means of displaying the wealth of Murid circuits, one could also see what is being concealed. The three quarter bust portraits and grandes boubous that reach the floor obscure the strip woven wrappers that serve as the basis of women's wealth and serve as exchange objects. Wrappers rarely appear in photographs today, which is in contrast to how prolifically they appear in Fortier's postcards and their occasional appearance in 
mid century studio photography as bed coverings, backdrops or wrapped around the upper body. One might focus on Robert Foster's (1993) notion of 'revelation' rather than reciprocity as wrappers are a form of wealth that can be highly visible as in the moment of circulation during a family ceremony, or invisible, as when they are stacked in a closed armoire or worn on the lower half of the body under a voluminous boubou. In revealing wealth, portraits persuade, 'by covering themselves with gold, then, kings persuade others to cover them with gold as well' (Graeber 1996: 9). In concealing wrappers, portraits allow women to withhold this valuable resource from circulation, 'the things kept allow a person to circulate other things' (Weiner 1985: 222).

As the appearance of wealth among families in Dakar's varied urban neighbourhoods has become disconnected from sources of production abroad through Murid trade, wealth and the images of wealth have become distorted. The means through which women and men make a living and earn enough money to send back as remittances to their families is not often visible to those at home. As such personal portraits speak to the promise of prosperity, a promise that is associated with transnationally connected urbanity, but that is often not delivered. Yet, this promise, rather than the actual transfer of wealth, is often sufficient to fulfil expectations of families and friends. Thus, through successful portraits women can connect to other women who hope to become the recipients of their future gifts, even when those gifts often do not, or cannot, materialize.

\section{CONCLUSION}

Commercial photographic practices reflect and remake the changing fortunes of young urban women from Murid families in Dakar's peripheral neighbourhoods. Popular photographic 
practices aimed at coming out better point to the precariousness of social subjects, their finances, and their sense of the prospects for the future. The preference for repetition and montage in photographic practices reflect young urban Muslim women's attempts to multiplying their grace as an instance of coming out better. These images are both the motivation and the outcome of a vast circulation of valuables and money including cloth and religious offerings, among other things, underpinning translocal circuits of wage labour and capital organized under the aegis of Tariqa Murid.

In this paper, I have analysed how Muslim women in urban spaces attempt to achieve respectability through the production and circulation of valued objects, such as photographs. Through field based research in the Khar Yalla neighbourhood of Dakar, I analysed how women invest value in others and how valued objects come to stand for ideal social relations that both point to and constitute a transnationally embedded community and its future. I have also suggested that the point is not whether or not those ideal social relations are realized, but rather, the creative forms of action that women take up.

Photographs, as valued objects and elements of visual culture, mediate, or create meaningful links, between subjective experience and encompassing economic changes. They help young Muslim women such as Amina and Fanta make sense and make do with the vast disparities they see in incomes and social possibilities in Dakar. These everyday photographic practices photographers and their subjects' collaborate to create new forms of value and meaningful action that characterize Africa's urban spaces. Dakar, like most African cities, has inequalities in access to wealth, education (both Western and Muslim education), technology and media, and work. Yet, young women create meaningful social worlds in spite of the financial troubles they experience through the production and circulation of self portraits and family 
photographs aimed at capturing and projecting an image of their happiness, luck (warsek), and religious grace (baraka). Muslim women such as Fanta and Amina seek to create and remake their social and moral personhood in tandem with these changing times. Their portraits succeed when they bridge the gap between what they see and what they experience, between themselves and others who are coming out better, and when they enable them to deal with the inconsistencies and incoherencies of urban life for young women.

\section{ACKNOWLEDGEMENTS}

I would like to thank my interlocutors in Dakar for their generosity and good will. To respect their privacy I have changed their names or not mentioned them specifically. My thinking about this manuscript has benefitted from the numerous conversations with colleagues: the students and faculty at the African Studies Workshop at the University of Chicago including Beth Brummel, Claudia Gastrow, Kate McHarry, and Jay Schutte, my colleagues at Indiana University including the Department of Anthropology, the African Studies Program, and the Mathers Museum of World Cultures, and Fabienne Ngóone Diouf, Wolof Associate Instructor and Doctoral Candidate at Indiana University. I would like to thank the editors of Africa, as well as the editors of this special issue, and the two anonymous reviewers for their thoughtful comments. All errors of fact or interpretation are entirely my own. Funding for this research was provided by a Faculty Curatorship at the Mathers Museum of World Cultures, and grants from the Office of the Vice President for International Affairs at Indiana University in 2010 and 2012. I would also like to thank the photographers and artists: Boubacar Toure Mandemory, George Osodi, Kaan Si, and Djibril Sy. 


\section{REFERENCES CITED}

Appadurai, A. (1986) 'Introduction: commodities and the politics of value' in A. Appadurai (ed), The Social Life of Things: commodities in cultural perspective. Cambridge: Cambridge University Press.

Bajorek, J. (2010) 'Photography and national memory: Senegal about 1960', History of Photography 34 (2): 158-69.

Behrend, H. (2010) 'Fragmented visions: photo collages by two Ugandan photographers', Visual Anthropology 14 (3): 301-20.

Bell, C. et al. (1996) In/sight: African photographers, 1940 to the present. New York: Guggenheim Museum.

Benjamin, W. et al. (2008) The Work of Art in the Age of its Technological Reproducibility, and Other Writings on Media. Cambridge, Massachusetts: Belknap Press of Harvard University Press.

--- (2001) 'The work of art in the age of mechanical reproduction' in H. Arendt (ed), Illuminations. New York: Schocken.

Bigham, E. (1999) 'Issues of authorship in the portrait photographs of Seydou Keita', African Arts 32 (1): 56-67.

Brennan, V. (2010) 'Mediating the voice of the spirit: musical and religious transformations in Nigeria's oil boom', American Ethnologist 37 (2): 354-70.

Buckley, L. M. (2000) 'Self and accessory in Gambian studio photography', Visual Anthropology Review 16 (2): 71-91.

Buggenhagen, B. (2010) 'Islam and the media of devotion in and out of Senegal', Visual Anthropology Review 26 (2): 81-95.

--- (2011) 'Are births just "women's business"? gift exchange, value, and global volatility in Muslim Senegal', American Ethnologist 38 (4): 714-32.

--- (2012) Muslim Families in Global Senegal : money takes care of shame. Bloomington, Indianapolis: Indiana University Press.

Chapuis, F. (1999) 'The pioneers of Saint Louis' in P.M. Saint Leon, N'Gone Fall, and F. Chapuis (eds), Anthology of African and Indian Ocean Photography. Paris: Editions revue noire.

Comaroff, J. L. and J. Comaroff (2000) 'Millennial capitalism: first thoughts on a second coming', Public Culture 12 (2): 291-343.

--- (2001) 'On personhood: an anthropological perspective from Africa', Social Identities 7 (2): 267-83.

Davis, M. (2006) Planet of Slums. New York: Verso.

Eickelman, D. F. and J. W. Anderson (2003) New Media in the Muslim World: the emerging public sphere. Bloomington: Indiana University Press.

Eisenlohr, P. (2006) 'As Makkah is sweet and beloved, so is Madina: Islam, devotional genres and electronic mediation in Mauritius', American Ethnologist 33 (2): 230-45.

Enwezor, O. and ICP (2006) Snap Judgments: new positions in contemporary African photography. New York: International Center of Photography.

Fall, A. S. (1999) 'Vague memory of a confiscated photo' in P.M. Saint Leon, N'Gone Fall, and F. Chapuis (eds), Anthology of African and Indian Ocean Photography. Paris: Revue Noire. 
Foster, R. J. (1993) 'Dangerous circulation and revelatory display' in J. Fajans (ed), Exchanging Products, Producing Exchange. Sydney: University of Sydney.

--- (2006) 'Tracking globalization. commodities and value in motion' in C. Tilley et al. (eds), Handbook of Material Culture. London: Sage Press.

Ginsburg, F. D., L. Abu-Lughod and B. Larkin (2002) Media Worlds: anthropology on new terrain. Berkeley: University of California Press.

Grabski, J. (2011) 'Market logics: how locality and mobility make artistic livelihoods in Dakar', Social Dynamics 37 (3): 321-331.

Graeber, David (1996) 'Beads and money: notes toward a theory of wealth and power', American Ethnologist 23: 1-32.

Guyer, Jane I. (2004) Marginal Gains: monetary transactions in Atlantic Africa. Chicago: University of Chicago Press.

Heath, D. (1992) 'Fashion, anti-fashion and heteroglossia in urban Senegal', American Ethnologist 19 (1): 19-33.

Hirschkind, Ch. (2006) 'Cassette ethics: public piety and popular media in Egypt' in B. Meyer and A. Moors (eds), Religion, Media and the Public Sphere. Bloomington: Indiana University Press.

Hirschkind, Ch. and B. Larkin (2008) 'Introduction to media and the political forms of religions', Social Text 26 (3):1-9.

Jones, H. (2013) The Metis of Senegal: urban life and politics in French West Africa. Bloomington: Indiana University Press.

Keane, W. (2001) 'Money is no object: materiality, desire and modernity in an Indonesian society' in F. R. Meyers (ed), The Empire of Things: regimes of value and material culture. Santa Fe: School of American Research Press.

Keita, S., A. Magnin and Y. Cissé (1997) Seydou Keïta. Zurich, New York: Scalo.

Lamunière, M. et al. (2001) You Look Beautiful Like That: the portrait photographs of Seydou Keïta and Malick Sidibé. Cambridge, New Haven: Harvard University Art Museums.

Landau, P. St. and D. D. Kaspin (2002) Images and Empires: visuality in colonial and postcolonial Africa. Berkeley: University of California Press.

Larkin, B. (2008) Signal and Noise: media, infrastructure, and urban culture in Nigeria. Durham: Duke University Press.

Magee, C. (2007) 'Spatial stories: photographic practices and urban belonging', Africa Today 54 (2): 109-129.

Makhulu, A.-M., B. Buggenhagen and St. Jackson (2010) Hard Work, Hard Times: global volatility and African subjectivities. Berkeley: University of California Press.

Mauss, M. (1990 [1950]) The Gift. New York: W.W. Norton \& Company, Inc.

Mazzarella, W. (2004) 'Culture, globalization, mediation', Annual Review of Anthropology 33: 345-67.

Mbembe, J. A. and S. Nuttall (2004) 'A blasé attitude: a response to Michael Watts', Public Culture 16 (3): 347-72.

Meyer, B. and A. Moors (2006) Religion, Media, and the Public Sphere. Bloomington: Indiana University Press.

Miessgang, Th. and B. Schröder (2001) Flash Afrique! Ausstellung Kunsthalle Wien, 7. September -11. November 2001. Wien, Göttingen: Kunsthalle.

Munn, N. D. (1992) The Fame of Gawa: a symbolic study of value transformation in a Massim (Papua New Guinea) Society. Durham: Duke University Press. 
Mustafa, H. N. (2002) 'Portraits of modernity: fashioning selves in dakarois popular photography' in D. D. Kaspin and P. St. Landau (eds), Images and Empires: visuality in colonial and postcolonial Africa. Berkeley: University of California Press.

Pinney, Ch. C. (1992) 'The parallel histories of anthropology and photography' in E. Edwards (ed), Anthropology and Photography. New Haven and London: Yale University Press.

--- (2003a) Introduction: how the other half...' in Pinney, Ch. and N. Peterson Photography's Other Histories. Durham: Duke University Press.

---(2003b) 'Notes from the surface of the image: photography, postcolonialism, and vernacular modernism' in Pinney, Ch. and N. Peterson Photography's Other Histories. Durham: Duke University Press.

Poole, D. (1997) Vision, Race, and Modernity: a visual economy of the Andean image world. Princeton, N.J.: Princeton University Press.

--- (2005) 'An excess of description: ethnography, race, and visual technologies', Annual Review of Anthropology 34 (1): 159-79.

Prochaska, D. (1991) 'Fantasia of the phototeque: French postcard views of colonial Senegal', African Arts 24 (4): 40-47.

Rabine, L. (2010) 'Fashionable photography in mid-twentieth century Senegal', Fashion Theory 14 (3): 305-30.

Roberts, A. F. (1996) 'The ironies of system D' in C. Cerny and S. Seriff (eds), Recycled, Reseen: folk art from the global scrap heap. New York: Harry Abrams for the Museum of International Folk Art Santa Fe.

Roberts, A. F. and M. N. Roberts (1998) 'L'Aura d'Amadou Bamba: photographie et fabulation dans le Senegal urbain', Anthropologie et Sociétés 22 (1): 15-40.

--- (2000) 'Displaying secrets. visual piety in senegal' in R. S. Nelson (ed), Visuality Before and Beyond the Renaissance: seeing as other saw. Cambridge: Cambridge University Press.

Roberts, A. F. et al. (2003) A Saint in the City: Sufi arts of urban Senegal. Los Angeles, California: UCLA Fowler Museum of Cultural History.

Schulz, D. E. (2006) 'Morality, community, publicness: shifting terms of public debate in Mali' in B. Meyer and A. Moors (eds), Religion, Media and the Public Sphere. Bloomington: Indiana University Press.

Simone, A. M. (2001) 'The worlding of African cities', African Studies Review 44 (2): 15-41.

--- (2006) 'Intersecting geographies? ICTs and other virtualities in urban africa' in M. S. Fisher and G. Downey (eds), Frontiers of Capital: ethnographic reflections on the new economy. Durham, NC: Duke University Press.

Sprague, St. (1978) 'Yoruba photography: how the Yoruba see themselves', African Arts 12 (1): 52-59, 107.

Spyer, P (2001) 'Photography's framings and unframings; a review article', Comparative Studies in Society and History 43 (1): 181-192.

Steiner, Ch. (2001) 'Rights of passage. on the liminal identity of art in the border zone' in F. Meyers (ed), Empire of Things: regimes of value and material culture. Santa Fe: School of American Research.

Strathern, M. (1988) The Gender of the Gift: problems with women and problems with society in Melanesia. Berkeley: University of California Press.

Watts, M. (2005) 'Baudelaire over Berea, Simmel over Sandton? ', Public Culture 17 (1): 181-92.

Weiner, A. B. (1985) 'Inalienable wealth', American Ethnologist 12 (2): 210-27. 
--- (1992) Inalienable Possessions: the paradox of keeping-while-giving. Berkeley: University of California Press.

--- (2001) 'A conversation with Annette Weiner' in F. Meyers (ed), The Empire of Things: regimes of value and material culture. Sante Fe: School of American Research.

Wilk, R. R. and K. M. Askew (2002) The Anthropology of Media: a reader. Malden, Massachusetts: Blackwell Publishers.

${ }^{1}$ Lurex is the trademark name of a dye resistant machine made metallic yarn produced in Leicester, UK

${ }^{2}$ Also, Djibril Sy, personal communication, December 2011.

${ }^{3}$ I have not included images of these albums to protect the identity of the two women.

${ }^{4}$ Khar Yalla is a neighbourhood within Grand Yoff.

${ }^{5}$ Talibe are generally the disciples of Sufi scholars. In this instance I am referring to children who are sent to urban areas by their families to be educated, socialized, and cared for by a Sufi scholar. In some instances, these children are sent to beg on the street on behalf of this scholar and may not receive adequate care or education.

${ }^{6}$ In 2000500 CFA francs would have been about \$1. In June 2013, a 500 CFA franc note would be about 97 cents or 0.76 Euros. In 2000 a woman in Khar Yalla might spend 1.500 CFA total to prepare lunch and dinner for a family of ten.

${ }^{7}$ In this image Bamba's head is cut off, which is typical of the quality of photos bought in the market, nonetheless disciples would consider this image efficacious.

ABSTRACT

Young women who live in the improvised urban spaces on the outskirts of Senegal's capital city, Dakar, extemporize their respectability in a time of fiscal uncertainty through personal photography. The neighbourhood of Khar Yalla, is an improvised, interconnected, and multilayered space settled by families removed from the city center during clean up campaigns from the 1960s to the 1970s, by families escaping conflict in Casamance and Guinea Bissau, and by recent rural migrants. As much as Khar Yalla is an improvised neighbourhood, it is also a space of improvisation. When women pose for, display, and pass around portraits of themselves at key moments in their social life, whether in the medium of social networking sites or photo albums, they reveal as much as they conceal the elements of individual and social life. They 
index their social networks and constitute their urban space not as peripheral, but as central to the lives and imaginations of their siblings and spouses who live abroad. Photographs actively shape and construct urban spaces, which are often loud, unruly, and fraught spaces with vast inequalities and incommensurabilities. How women deal with economic and social disparity, within their own families, communities, and globally, is the subject of this paper.

\section{FIGURES}

1. Figure 1: Postcard image by François-Edmond Fortier titled "Femmes du Cayor," 18901905(?). "1199. Afrique Occidentale - SÉNÉGAL - Femmes du Cayor Collection Général Fortier, Dakar" [printed on front]; “CARTE POSTALE...” [printed on back; continues]. Copyright: The British Museum (see "Using Digital Images of Objects in this Collection: http://www.britishmuseum.org/join_in/using_digital_images/using_digital_images.aspx? asset id=79284\&objectId=1410731\&partId=1 for permissions, which they grant for research publications)

2. Figure 2: Piven, J.L. eds. (1996). Mama Casset et les precurseurs de la photographie au Senegal, 1950, Meissa Gaye, Mix Gueye, Adama Sylla, Alioune Diouf, Doro Sy, Doudou Diop, Salla Ca (Collection Soleil), Editions Revue Noire.

3. Figure 3: Image from the IFAN (Institut français de l'Afrique noire) collection, Dakar, Senegal. Taken in the 1950s, there is no further information available on these photos.

4. Figure 4: A photograph of Murid shaykhs bought in Sandaga market in Dakar. Photographer unknown.

5. Figure 5: A wedding portrait taken in 1999. Photographer unknown. 
$\longrightarrow$ 